ESJ Natural/Life/Medical Sciences

\title{
Impact of Bias Correction on Present and Mid-Future Rainfall Projections over Senegal
}

\section{Sarr Alioune Badara}

Laboratoire d'Océanographie, des Sciences de l'Environnement et du Climat (LOSEC), UFR Sciences et Technologies, Université A. SECK de Ziguinchor, Sénégal

IRD-ESPACE-DEV, Maison de la Télédétection, Montpellier Cedex, France

\section{Diatta Samo}

Laboratoire d'Océanographie, des Sciences de l'Environnement et du Climat (LOSEC), UFR Sciences et Technologies, Université A. SECK de Ziguinchor, Sénégal

Laboratoire Physique de l'Atmosphére et de l’Océan-Simeon Fongang, ESP, Université Cheikh Anta DIOP, Sénégal

\section{Kébé Ibourahima}

West African Science Service Center on Climate Change and Adapted Landuse (WASCAL), WASAL Competence Center, Boulevard Mouammar Kadhafi, Ouagadougou, Burkina Faso

Université Nazi Boni, Centre Universitaire de Banfora, Burkina Faso

\section{Sultan Benjamin}

IRD-ESPACE-DEV, Maison de la Télédétection, Montpellier Cedex, France Camara Moctar

Laboratoire d'Océanographie, des Sciences de l'Environnement et du Climat (LOSEC)

\section{Doi:10.19044/esj.2021.v17n37p137}

Submitted: 08 June 2020

Accepted: 22 September 2021

Published: 31 October 2021
Copyright 2021 Author(s)

Under Creative Commons BY-NC-ND 4.0 OPEN ACCESS

Cite As:

Sarr A.B., Diatta S., Kébé I., Sultan B. \& Camara M. (2021). Impact of Bias Correction on Present and Mid-Future Rainfall Projections over Senegal. European Scientific Journal, ESJ, 17(37), 137.

https://doi.org/10.19044/esj.2021.v17n37p137

\section{Abstract}

In this study, we analyze the impact of bias correction models on present and future precipitation and extremes rainfall events over Senegal. The commonly used linear scaling (LS) bias correction method has been applied 
on four (4) regional climate models (RCMs) of the Coordinated Regional Climate Downscaling Experiment (CORDEX) program. The linear scaling bias correction method was firstly calibrated and validated during the 19761990 and 1991-2005 periods, respectively. The comparison with the observed data revealed that the linear scaling method significantly improves the mean and the extreme precipitations during the validation period. The RCMs generally simulate a decrease of rainfall in the mid-twenty-first century under the RCP8.5 greenhouse gas concentration pathway compared to the reference period (1976-2005), except for the CCLM4 and the RCA4 models which show respectively a slight increase overall Senegal and the east of the country. The changes in precipitation indices such as the number of wet days (R1mm) and mean frequency of heavy rainfall events (R20mm) follows that mean precipitation change distribution. Almost uncorrected RCMs (except RCA4) predict during the near future an increase in of the mean intensity of daily rainfall events (SDII), the mean intensity of precipitation events above the 95th Percentile (R95PTOT) and the mean maximum dry spells length (CDD), whereas a decrease in the mean maximum wet spells length (CWD) is projected. After applying the LS bias correction, the spatial distribution patterns are not so much modified in all the models but the magnitude of the climate change signal is either amplified or moderated depending on the considered variables.

Keywords: Regional Climate Models, Coordinated Regional Climate Downscaling Experiment (CORDEX), Climate Change Signal, Bias Correction, Senegal

\section{Introduction}

Knowing the climate and rainfall extremes trends in the near future is a great challenge and is very important for Sahelian countries including Senegal, whose economy depends mainly on agriculture and animal husbandry. Indeed, climate projections made in the Sahel and particularly in Senegal (Sylla et al. 2016; Diallo et al. 2016; Sarr and Camara 2017) have shown a possible reduction of mean precipitation and an increase in extreme events. To study the impact of climate change in the Sahel, Global Climate Models (GCMs) have often been used. However, several studies (Kim et al. 2014; Akinsanola et al. 2018) have shown the presence of significant bias in the GCMs especially in simulating the precipitation which the variability widely varies from one model to another. GCMs have difficulties simulating several surface heterogeneities because of their low spatial resolution (200 to $300 \mathrm{~km}$ ). To refine the diagnosis at regional or local scales, regional climate models (RCMs) have been increasingly used to dynamically disaggregate GCMs (Paeth et al. 2008). In this context, several experiments have been undertaken 
to produce coordinated experiments using several regional climate models (RCMs). These include PRUDENCE (Christensen et al., 2008), ENSEMBLES-AMMA (van der Linden and Mitchell 2009), and recently the CORDEX program (Giorgi et al., 2009, Nikulin et al., 2012). Several studies have shown the persistence of these biases in the RCMs, especially in certain areas such as West Africa (Nikulin et al. 2012, Camara et al. 2013, Sarr et al. 2015). Indeed, the parameterization in the models remains a crucial problem despite the increase in the resolution. So, the simulated climates are not still in perfect agreement with the observations mainly at the local scale. To address this issue, several authors (Hayhoe et al. 2007; Hawkins et al. 2012; Ahmed et al. 2012) have recommended the use of bias corrections on climate model outputs. Several bias-corrected methods have been tested in West Africa or in other areas of the world. Mbaye et al. (2015) have used the delta function method to bias correct the REMO model over the Senegal river basin; Teutschbein and Seibert (2013) have tested the performance of four bias correction methods in five (5) catchments in Sweden. Recently, Mahmood et al. (2018) have highlighted the performance of precipitation extended linear scaling method for correcting GCMs in the Jhelum river basin.

The objective of our study is to test the ability of the widely used linear scaling (LS) method (Imbery et al. 2013, Dahm et al. 2016) to correct first the biases from precipitation simulated by the regional climate models of the CORDEX program (COordinated Regional climate Downscaling Experiment) in Senegal; and secondly to analyze the impact of the LS method on the projected mean and extreme precipitation under the Representative Concentration Pathway 8.5 (RCP8.5) in Senegal.

\section{Data and method}

\subsection{Study area and observation dataset}

The study area is Senegal (figure 1) country in West Africa located between latitude $12^{\circ} 30 \mathrm{~N}-16^{\circ} 30 \mathrm{~N}$ and longitude $11^{\circ} 30 \mathrm{~W}-17^{\circ} 30 \mathrm{~W}$. The climate, predominantly Sahelian, is characterized by two unevenly distributed seasons characterized by a short rainy season in the north from July to September, to a relatively short in the south from June to September and a long dry season from November to May subject to the predominance of hot and dry flows. During the rainy season, an increase in rainfall gradient is noted that shifts southward (Salack et al. 2012).

Daily data from 35 rain gauge stations located in Senegal have been used in this study (table 1, Figure 1). These daily datasets have been provided by the National Agency for Civil Aviation and Meteorology of Senegal (ANACIM) and span from the period 1950-2014. The natural neighbor method that is based on a weighted average of local data (Ledoux and Gold, 2005), has been used for spatial interpolation. 


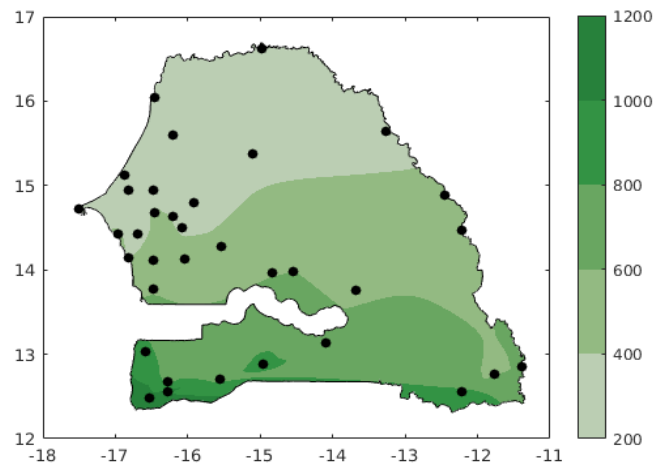

Figure 1. Mean summer precipitation (1991-2005), points indicate the location of the rain gauge stations network of the National Agency for Civil Aviation and Meteorology

Table 1. Stations of the National Agency for Civil Aviation and Meteorology of Senegal used in this study

\begin{tabular}{|c|c|c|c|c|}
\hline Stations name & Longitude & Latitude & UTM Zone & Altitude \\
\hline Baba Garage & $-16^{\circ} 28^{\prime} 48^{\prime \prime}$ & $14^{\circ} 57^{\prime} 00^{\prime \prime}$ & $28 \mathrm{P}$ & $24 \mathrm{~m}$ \\
\hline Bakel & $-12^{\circ} 27^{\prime} 36^{\prime \prime}$ & 145'ㄴ' & $28 \mathrm{P}$ & $25 \mathrm{~m}$ \\
\hline Bambey & $-16^{\circ} 27^{\prime} 00^{\prime \prime}$ & $14^{\circ} 40^{\prime} 48^{\prime \prime}$ & $28 \mathrm{P}$ & $21 \mathrm{~m}$ \\
\hline Bignona & $-16^{\circ} 16^{\prime} 12^{\prime \prime}$ & $12^{\circ} 40^{\prime} 12^{\prime \prime}$ & $28 \mathrm{P}$ & $31 \mathrm{~m}$ \\
\hline Boulel & $-15^{\circ} 31^{\prime} 48^{\prime \prime}$ & $14^{\circ} 16^{\prime} 48^{\prime \prime}$ & $28 \mathrm{P}$ & $31 \mathrm{~m}$ \\
\hline Dakar-Yoff & $-17^{\circ} 30^{\prime} 36^{\prime \prime}$ & $14^{\circ} 43^{\prime} 12^{\prime \prime}$ & $28 \mathrm{P}$ & $27 \mathrm{~m}$ \\
\hline Diouloulou & $-16^{\circ} 34^{\prime} 48^{\prime \prime}$ & $13^{\circ} 01^{\prime} 48^{\prime \prime}$ & $28 \mathrm{P}$ & $12 \mathrm{~m}$ \\
\hline Diourbel & $-16^{\circ} 12^{\prime} 00^{\prime \prime}$ & $14^{\circ} 38^{\prime 2} 24^{\prime \prime}$ & $28 \mathrm{P}$ & $7 \mathrm{~m}$ \\
\hline Foudiougne & $-16^{\circ} 28^{\prime} 12^{\prime \prime}$ & 1407'12" & $28 \mathrm{P}$ & $6 \mathrm{~m}$ \\
\hline Gossas & $-16^{\circ} 04^{\prime} 48^{\prime \prime}$ & $14^{\circ} 30^{\prime} 00^{\prime \prime}$ & $28 \mathrm{P}$ & $21 \mathrm{~m}$ \\
\hline Kaffrine & $-16^{\circ} 48^{\prime} 36^{\prime \prime}$ & $14^{\circ} 06^{\prime} 00^{\prime \prime}$ & $28 \mathrm{P}$ & $16 \mathrm{~m}$ \\
\hline Kaolack & $-16^{\circ} 02^{\prime} 24^{\prime \prime}$ & $14^{\circ} 07^{\prime} 48^{\prime \prime}$ & $28 \mathrm{P}$ & $9 \mathrm{~m}$ \\
\hline Kédougou & $-12^{\circ} 12^{\prime} 36^{\prime \prime}$ & $12^{\circ} 33^{\prime} 36^{\prime \prime}$ & $28 \mathrm{P}$ & $178 \mathrm{~m}$ \\
\hline Kidira & $-12^{\circ} 13^{\prime} 12^{\prime \prime}$ & $14^{\circ} 28^{\prime} 12^{\prime \prime}$ & $28 \mathrm{P}$ & $39 \mathrm{~m}$ \\
\hline Kolda & $-14^{\circ} 57^{\prime} 36^{\prime \prime}$ & $12^{\circ} 52^{\prime} 48^{\prime \prime}$ & $28 \mathrm{P}$ & $10 \mathrm{~m}$ \\
\hline Koumpentoum & $-14^{\circ} 33^{\prime} 00^{\prime \prime}$ & $13^{\circ} 58^{\prime} 48^{\prime \prime}$ & $28 \mathrm{P}$ & $27 \mathrm{~m}$ \\
\hline Koungheul & $-14^{\circ} 49^{\prime} 48^{\prime \prime}$ & $13^{\circ} 58^{\prime} 12^{\prime \prime}$ & $28 \mathrm{P}$ & $17 \mathrm{~m}$ \\
\hline Linguère & $-15^{\circ} 06^{\prime} 00^{\prime \prime}$ & $15^{\circ} 22^{\prime} 48^{\prime \prime}$ & $28 \mathrm{P}$ & $24 \mathrm{~m}$ \\
\hline Louga & $-16^{\circ} 12^{\prime} 00^{\prime \prime}$ & $15^{\circ} 36^{\prime} 00^{\prime \prime}$ & $28 \mathrm{P}$ & $41 \mathrm{~m}$ \\
\hline Matam & $-13^{\circ} 15^{\prime} 36^{\prime \prime}$ & 15०38'24" & $28 \mathrm{P}$ & $19 \mathrm{~m}$ \\
\hline Mbacké & $-15^{\circ} 55^{\prime} 12^{\prime \prime}$ & $14^{\circ} 48^{\prime} 00^{\prime \prime}$ & $28 \mathrm{P}$ & $47 \mathrm{~m}$ \\
\hline Mborro & $-16^{\circ} 52^{\prime} 48^{\prime \prime}$ & $15^{\circ} 07^{\prime} 48^{\prime \prime}$ & $28 \mathrm{P}$ & $20 \mathrm{~m}$ \\
\hline Mbour & $-16^{\circ} 58^{\prime} 12^{\prime \prime}$ & $14^{\circ} 25^{\prime} 12^{\prime \prime}$ & $28 \mathrm{P}$ & $15 \mathrm{~m}$ \\
\hline Oussouye & $-16^{\circ} 31^{\prime} 48^{\prime \prime}$ & $12^{\circ} 28^{\prime} 48^{\prime \prime}$ & $28 \mathrm{P}$ & $20 \mathrm{~m}$ \\
\hline Podor & $-14^{\circ} 58^{\prime} 12^{\prime \prime}$ & $16^{\circ} 37^{\prime} 12^{\prime \prime}$ & $28 Q$ & $9 \mathrm{~m}$ \\
\hline Saint-Louis & $-16^{\circ} 27^{\prime} 00^{\prime \prime}$ & $16^{\circ} 02^{\prime} 24^{\prime \prime}$ & $28 Q$ & $22 \mathrm{~m}$ \\
\hline Sédhiou & $-15^{\circ} 33^{\prime} 0 "$ & $12^{\circ} 41^{\prime 2} 24^{\prime \prime}$ & $28 \mathrm{P}$ & $23 \mathrm{~m}$ \\
\hline Tambacounda & $-13^{\circ} 40^{\prime} 48^{\prime \prime}$ & $13^{\circ} 45^{\prime} 36^{\prime \prime}$ & $28 \mathrm{P}$ & $33 \mathrm{~m}$ \\
\hline Thiadiaye & $-16^{\circ} 42^{\prime} 0^{\prime \prime}$ & $14^{\circ} 25^{\prime} 12^{\prime \prime}$ & $28 \mathrm{P}$ & $26 \mathrm{~m}$ \\
\hline Tivaoune & $-16^{\circ} 48^{\prime} 00^{\prime \prime}$ & $14^{\circ} 57^{\prime} 00^{\prime \prime}$ & $28 \mathrm{P}$ & $57 \mathrm{~m}$ \\
\hline
\end{tabular}




\begin{tabular}{|c|c|c|c|c|}
\hline Toubacouta & $-16^{\circ} 28^{\prime} 48^{\prime \prime}$ & $13^{\circ} 46^{\prime} 48^{\prime \prime}$ & $28 \mathrm{P}$ & $15 \mathrm{~m}$ \\
\hline Vélingara & $-14^{\circ} 06^{\prime} 00^{\prime \prime}$ & $13^{\circ} 08^{\prime} 24^{\prime \prime}$ & $28 \mathrm{P}$ & $33 \mathrm{~m}$ \\
\hline Ziguinchor & $-16^{\circ} 16^{\prime} 12^{\prime \prime}$ & $12^{\circ} 33^{\prime} 36^{\prime \prime}$ & $28 \mathrm{P}$ & $33 \mathrm{~m}$ \\
\hline Saraya & $-11^{\circ} 46^{\prime} 12^{\prime \prime}$ & $12^{\circ} 46^{\prime} 12^{\prime \prime}$ & $29 \mathrm{P}$ & $182 \mathrm{~m}$ \\
\hline Kenieba & $-11^{\circ} 13^{\prime} 12^{\prime \prime}$ & $12^{\circ} 51^{\prime} 00^{\prime \prime}$ & $29 \mathrm{P}$ & $88 \mathrm{~m}$ \\
\hline
\end{tabular}

\subsection{Models description}

Four (4) regional climate models (RCMs) from the CORDEX program are considered in this study (Table 2). The horizontal resolution of the models is $0.44^{\circ} \times 0.44^{\circ}$. The RACMO and REMO models are driven by the Global Climate Model (GCM) EC-EARTH, while the RCA4 and CCLM4 models are driven by the CNRM-CM5 as shown in table 2. Two periods have been considered in this study, the reference period or historical period that lays from 1976 to 2005 and the near-future period that goes from 2036-2065 and corresponds to the mid-twenty-first century. Climate projections used here are forced by the Representative Concentration Pathway (RCP) 8.5 as described in Moss et al. (2010). It represents the prescribed greenhouse gas concentration pathway throughout the twenty-first century that corresponds to a radiative forcing of $8.5 \mathrm{~W} \cdot \mathrm{m}^{-2}$ known as the high-level emission scenario.

Table 2. Description of the regional climate models

\begin{tabular}{|c|c|c|c|}
\hline Name & GCM forcing & Institution & References \\
\hline CCLM4 & CNRM-CM5 & CLM-community & Baldauf et al., (2011) \\
\hline RACMO22T & EC-EARTH & $\begin{array}{c}\text { KNMI, The } \\
\text { Netherlands }\end{array}$ & Van Meijgaard et al., (2008) \\
\hline RCA4 & CNRM-CM5 & SMHI, Sweden & Samuelsson et al., (2011) \\
\hline REMO & EC-EARTH & MPI, Germany & Jacob et al., (2007) \\
\hline
\end{tabular}

\subsection{The Linear scaling (LS) bias correction}

The linear scaling method (Lenderink et al. 2007) adjusts rainfall of RCM simulations with correction values based on the relationship between long-term monthly mean observed and RCM control run values. The rainfall is adjusted using a multiplicative factor. It aims to perfectly match the longterm monthly mean of corrected values with those observed. The multiplicative factor is developed by comparing the observed data with the corresponding historical RCMs simulations and then applied to each daily value of the entire time series of the RCMs. It is widely used (Mendez et al. 2020, Worku et al. 2019, Willkofer et al. 2018, Mahmood et al. 2018, amount others) and is easy to implement (Shrestha et al. 2017). It is given by the following formula:

$$
P_{R C M, \text { cor }, m, d}=P_{R C M, m, d} * \frac{\overline{P_{o b s, m}}}{\overline{P_{R C M, m}}}
$$


Where $P_{\mathrm{RCM}, \text { cor,m,d }}$ and $P_{\mathrm{RCM}, \mathrm{m}, \mathrm{d}}$ are respectively the corrected and the uncorrected precipitation on the $\mathrm{d}^{\text {th }}$ day of $\mathrm{m}^{\text {th }}$ month. ${\overline{P_{o b s, m}}}_{\text {and }} \overline{P_{R C M, m}}$ are respectively the mean values of daily observed and simulated data of $\mathrm{m}^{\text {th }}$ month during the calibration period. The corrected factor $\left(\frac{\overline{P_{\text {obs }, m}}}{{ }^{R C M, m}}\right)$ remains unchanged during the validation and future periods. The calibration period spans from 1976 to1990 whereas the validation goes from 1991 to 2005. The reference dataset is rainfall data from the 35 rain gauge stations (from the ANACIM) located around Senegal.

\subsection{Precipitation indices}

The spatial distribution of rain in the summer period (June-September) as well, extreme precipitation indices derived from the Expert Team on Climate Change Detection and Indices (ETCCDI) and recommended by the World Meteorological Organization (WMO), have been analyzed. The ETCCDI indices have been widely used and provide daily statistics to assess changes in temperature and precipitation regimes on duration, intensity, and occurrence (Diatta et al. 2020, Sillman et al. 2013, Zhang et al. 2011, Peterson et al, 2001, etc.). In this work, we focused only on six (6) extreme precipitation indices that seemed to be most relevant for our study area and are compiled in Table 3.

Table 3. List and description of extreme precipitation indices

\begin{tabular}{|c|c|c|c|}
\hline $\begin{array}{c}\text { Indices } \\
\text { acronyms }\end{array}$ & Indices names & Description & units \\
\hline R1mm & Number of wet days & $\begin{array}{c}\text { number of days with } \\
\text { precipitation }>1 \mathrm{~mm}\end{array}$ & days \\
\hline R20mm & $\begin{array}{c}\text { Number of very heavy rainfall } \\
\text { events }\end{array}$ & $\begin{array}{c}\text { Maximum number of days } \\
\text { with precipitation }>20 \mathrm{~mm}\end{array}$ & days \\
\hline SDII & Daily precipitation intensity & $\begin{array}{c}\text { Precipitation intensity due } \\
\text { the wet days only }\end{array}$ & mm/day \\
\hline CWD & $\begin{array}{c}\text { Mean maximum wet spell } \\
\text { length }\end{array}$ & $\begin{array}{c}\text { Maximum number of } \\
\text { consecutive days with } \\
\text { cumulative daily rainfall } \\
\text { greater than 1mm/day }\end{array}$ & days \\
\hline CDD & $\begin{array}{c}\text { Maximum number of } \\
\text { consecutive days with } \\
\text { cumulative daily rainfall } \\
\text { lower than 1mm/day }\end{array}$ & days \\
\hline R95PTOT & $\begin{array}{c}\text { Total precipitation percent due } \\
\text { to heavy rain days }\end{array}$ & $\begin{array}{c}\text { Percentage sum of daily } \\
\text { precipitation }>95^{\text {th }} \\
\text { percentile }\end{array}$ & \% \\
\hline
\end{tabular}




\section{Results}

\subsection{Evaluation of the RCMs and the LS method}

Figure 2 shows the distribution of precipitation observed in Senegal (Fig.2.a) during the summer (June-September) and the biased distributions of RCMs without correction (Fig.2.b-f) and with correction applied (Fig.2.e-k) with respect to the observations during the validation period (1991-2005). The observations show a latitudinal distribution of precipitation from the south to north with larger amounts in southern Senegal. The uncorrected RCMs show fairly large biases across the country. The REMO_raw and RCA4_raw models (Fig.2b and Fig.2d, respectively) overestimate the intensity of precipitation over most parts of Senegal. However, the RCA4 model shows a strong underestimation of around $4 \mathrm{~mm}$ in the southwestern part of Senegal. Fig.2.c presents the bias distribution of precipitation simulated by the CCLM4_raw model. A high underestimation of the precipitation (about $3 \mathrm{~mm}$ ) is observed in almost all parts of Senegal. The uncorrected RACMO model (RACMO_raw) (Fig. 2.e) presents an important negative bias in the middle and south parts of the country that is generally less than $2 \mathrm{~mm}$ in absolute value. However, it slightly overestimates the precipitation in the eastern and northwestern parts of the country. When considering the uncorrected ensemble-mean, we note that these biases are relatively lower (Figure 2.f) with a very slight overestimation of precipitation (below $1 \mathrm{~mm}$ ) over almost all parts of Senegal except in the south where the precipitation is slightly underestimated. The reduction of the biases found with the ensemble mean is in agreement with the Nikulin et al. (2012), Kim et al. (2014), and Gbobaniyi et al. (2014) findings, which showed that the ensemble-mean model improves the performance of the models taken individually.

When applying the linear scaling (LS) bias correction method, the majority of corrected models show a remarkable reduction of precipitation magnitude in the whole country. For instance, the bias-corrected models such as REMO and RCA4 (Fig.2g and Fig.2i, respectively) show a reduction in absolute values from $3.5 \mathrm{~mm} /$ day to $0.5 \mathrm{~mm} /$ day. It should be noted that the uncorrected RCA4 and REMO models which present a wet bias in southern Senegal, exhibit a considerably reduced bias after correction. 


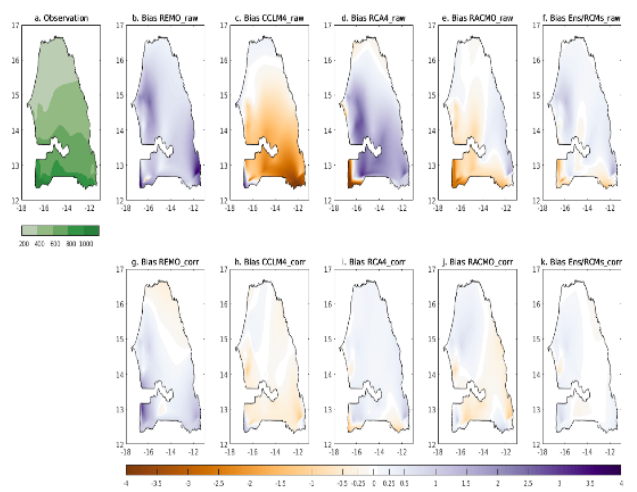

Figure 2. a. observed mean summer rainfall for the validation period (1991-2005) and the bias of uncorrected RCMs and their ensemble mean (b. REMO_raw, c. CCLM4_raw, d. RCA4_raw, e. RACMO_raw, f. Ens/RCMs_raw) (upper row) and the bias-corrected RCMs and their ensemble mean (g. REMO_corr, h. CCLM4_corr, i. RCA4_corr, j. RACMO_corr,

j. Ens/RCMs_corr) (lower row) with respect to the observation expressed in $\mathrm{mm} /$ days

To better investigate the performance of the LS method, the mean bias (in \%) and the root mean square error (in $\mathrm{mm} /$ day) of mean and extreme precipitation are shown in table 4 . The analysis of table 4 reveals that uncorrected models present the largest model error. The reduction of the error between uncorrected and corrected models is more felt with the mean precipitation. The model errors are also reduced in the extreme precipitation simulations corrected by the LS method with a lower rank than previously. Then, the LS exhibits a good score for most of the precipitation indices. This performance of the LS bias correction method gives good confidence in the analysis of the mid-twenty-first century rainfall spatial distribution changes.

Table 4. Mean bias (MB) expressed in \%, root mean square error (RMSE) expressed in $\mathrm{mm} /$ day to observation during the validation period (1991-2005)

\begin{tabular}{|c|c|c|c|c|c|c|c|c|c|c|c|c|c|c|c|c|c|c|c|c|}
\hline & \multicolumn{4}{|c|}{ CCLM4 } & \multicolumn{4}{|c|}{ RCA4 } & \multicolumn{4}{|c|}{ RACMO } & \multicolumn{4}{|c|}{ REMO } & \multicolumn{4}{|c|}{ Ens $\mathrm{RCM}$} \\
\hline & \multicolumn{2}{|c|}{ Raw } & \multicolumn{2}{|c|}{ corr } & \multicolumn{2}{|c|}{ Raw } & \multicolumn{2}{|c|}{ Corr } & \multicolumn{2}{|c|}{ Raw } & \multicolumn{2}{|c|}{ Corr } & \multicolumn{2}{|c|}{ Raw } & \multicolumn{2}{|c|}{ corr } & \multicolumn{2}{|c|}{ raw } & \multicolumn{2}{|c|}{ corr } \\
\hline & bias & $\begin{array}{c}\text { Rms } \\
\mathrm{e}\end{array}$ & bias & minse & Bias & $\begin{array}{c}\text { Rms } \\
\mathrm{e}\end{array}$ & bias & mse & Bias & rmse & bias & minse & bias & minse & bias & rmse & bias & minse & bras & rmse \\
\hline mean & $-17,48$ & 7.09 & -5.74 & 6.11 & 22.16 & 7,04 & 5.880 & 6.61 & 0.61 & 6.81 & 0.23 & 6.66 & 30.67 & 7.78 & 8.00 & 7.18 & 8.89 & 7.18 & 2.16 & 6.64 \\
\hline Rlmm & 33.74 & $\begin{array}{c}12.9 \\
2\end{array}$ & 30.05 & $\begin{array}{c}12.9 \\
1\end{array}$ & $\begin{array}{c}120.7 \\
8\end{array}$ & $\begin{array}{c}36.4 \\
4\end{array}$ & $\begin{array}{c}117.3 \\
1\end{array}$ & $\begin{array}{c}35.2 \\
2\end{array}$ & $\begin{array}{c}101.6 \\
4\end{array}$ & $\begin{array}{c}30.1 \\
7\end{array}$ & $\begin{array}{c}100.0 \\
6\end{array}$ & $\begin{array}{c}29.8 \\
6\end{array}$ & 83.21 & $\begin{array}{c}25.1 \\
1\end{array}$ & 74.26 & $\begin{array}{c}23.2 \\
8\end{array}$ & 84.84 & $\begin{array}{c}26.1 \\
6\end{array}$ & 80.42 & $\begin{array}{c}25.3 \\
2\end{array}$ \\
\hline R20mm & -43.98 & 5.85 & -33.19 & 4.60 & -64.13 & 6.51 & -52.68 & 5.86 & -56.93 & 6.55 & -49.56 & 5.98 & -36.01 & 5.08 & -16.96 & 4.76 & -50.26 & 5.99 & -38.10 & 5.30 \\
\hline SDII & -37.15 & 6.17 & -22.59 & 3.86 & -43.16 & 7.88 & 4.01 & 4.01 & -51.70 & 8.42 & -48.22 & 7.85 & -34.82 & 6.17 & -25.81 & 4.77 & -41.71 & 7.16 & -23.15 & 5.12 \\
\hline R95Ptot & 60.00 & $\begin{array}{c}12.3 \\
9\end{array}$ & 37.83 & 7.80 & 2.19 & 3.58 & 0.57 & 3.36 & 73.33 & $\begin{array}{c}150 \\
2\end{array}$ & 71.48 & 14.7 & 63.64 & $\begin{array}{c}13.1 \\
0\end{array}$ & 5998 & $\begin{array}{c}12.4 \\
3\end{array}$ & 49.79 & $\begin{array}{c}11.0 \\
2\end{array}$ & 42.46 & 9.57 \\
\hline CDD & -19.94 & $\begin{array}{c}21.6 \\
6\end{array}$ & -15.07 & $\begin{array}{c}21.0 \\
0\end{array}$ & -56.28 & $\begin{array}{c}21.0 \\
5\end{array}$ & -56.19 & $\begin{array}{c}20.7 \\
7\end{array}$ & -60.64 & $\begin{array}{c}21.3 \\
1\end{array}$ & -54.88 & $\begin{array}{c}20.4 \\
4\end{array}$ & -58.64 & $\begin{array}{c}20.6 \\
5\end{array}$ & -55.61 & $\begin{array}{c}20.2 \\
2\end{array}$ & -48.12 & $\begin{array}{c}21.1 \\
7\end{array}$ & -46.20 & $\begin{array}{c}20.6 \\
1\end{array}$ \\
\hline CWD & 78.21 & 3.43 & 86.74 & 3.73 & $\begin{array}{c}242.4 \\
4\end{array}$ & 9.69 & $\begin{array}{c}230.1 \\
3\end{array}$ & 9.21 & $\begin{array}{c}234.4 \\
9\end{array}$ & 955 & $\begin{array}{c}192.7 \\
6\end{array}$ & 7.78 & $\begin{array}{c}1136 \\
3\end{array}$ & 4.77 & $\begin{array}{c}104.1 \\
3\end{array}$ & 4.50 & $\begin{array}{c}164.1 \\
1\end{array}$ & 6.94 & $\begin{array}{c}156.5 \\
2\end{array}$ & 6.23 \\
\hline
\end{tabular}




\subsection{Projected change in precipitation and extreme precipitations}

Figure 3 shows the relative rainfall change between the near future (2036-2065) and the historical period (1976-2005) for both the uncorrected models (Figs.3.a-e) and the corrected models (Fig.3 f-j). The results show a low rainfall change with three uncorrected models (CCLM4_raw, RCA4_raw, and RACMO_raw) and the ensemble-mean as seen in Figures 3.b-d. The CCLM4_raw model (Fig. 3.b) shows a slight increase in precipitation signal (between 10 and 30\%) over the whole region. While the RCA4_raw model (Fig. 3c) reveals approximately more than $10 \%$ increase of precipitation signal over the east and $10 \%$ to $20 \%$ of reduction toward the west of the country. The RACMO_raw (Fig. 3.d) simulates a low decrease of rainfall over a large part of the country except in the southern area. Figure 3.a shows the distribution of change in precipitation simulated by the REMO_raw; it shows a north-south gradient of change with an intense decrease toward the north. The ensemblemean of the models (Fig. 3.e) shows little rainfall changes with a slight increase over the southern and a slight decrease over the northern part of the country (between 50 and 60\%). Corrected models present in general a similar spatial distribution of precipitation compared to the original models with different magnitudes (Figures 3.f-j). Indeed, the corrected models predict much stronger changes compared to the uncorrected models but with different behavior from a model to another. For instance, the REMO_corr (Figure 3.f) displays a high decrease in precipitation in the mid-twenty-first century which is more accentuated in the northern part (more than 80\%). Similar behavior is also observed with the ensemble-mean that shows an increase of the change from $10 \%$ to $20 \%$ (Fig. 3.j), and the RACMO_corr which increases the change between $10 \%$ and $50 \%$ (Fig 3.i). Few differences are noted in the spatial pattern changes between RACMO_raw and RACMO_corr. An east-west decrease of the gradient of rainfall change along the country is simulated by the RACMO_corr, while a north-south gradient in change is exhibited by the RACMO_raw. One interesting thing is that the spatial pattern of rainfall change is almost the same as the REMO_raw and the REMO_corr. Therefore, it can conclude that the applied bias correction on REMO does not alter the nature and the spatial pattern of change. This result is similar to Mbaye et al. (2015) findings when they applied the CDFt bias correction method to REMO over Senegal rivers. The LS method does not also change the spatial pattern in the CCLM4_corr and RCA4_corr (Figs 3.g and Figs 3.h, respectively) compared to the uncorrected models but the magnitudes are not the same. The bias-corrected models show more pronounced change compared to uncorrected models.

To characterize the extremes of precipitation, the mean frequency of wet days (R1mm), the mean frequency of heavy rainfall events (R20mm), the mean intensity of precipitation events above the 95th Percentile (R95Ptot), the 
mean maximum dry spell length (CDD) and the mean maximum wet spell length (CWD) have been analyzed.

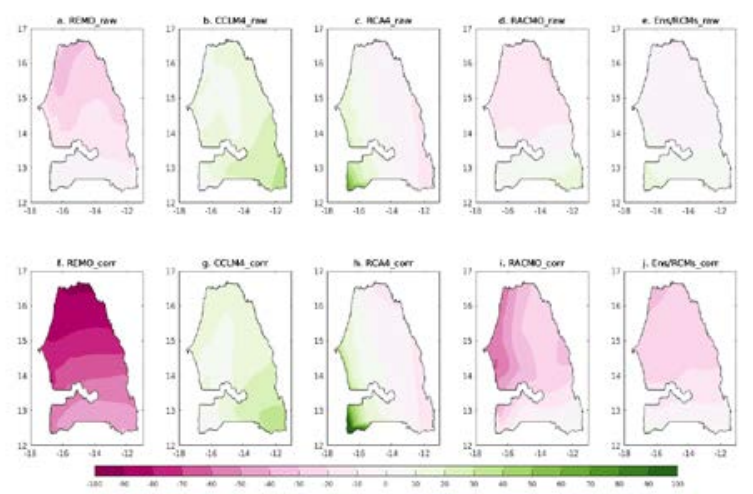

Figure 3. Mean summer projected rainfall change in \% (2036-2065 minus 1976-2005) for each RCMs and their ensemble-mean, uncorrected models are in the upper row (a.

REMO_raw, b. CCLM4_raw, c. RCA4_raw, d. RACMO_raw, e. Ens/RCMs_raw) and corrected models are in the lower row (f. REMO_corr, g. CCLM4_corr, h. RCA4_corr, i. RACMO_corr, j. Ens/RCMs_corr)

Figures 4 and 5 show respectively the projected changes in the number of rainy days (R1mm) and the frequency of heavy rainfall events (R20mm) in the uncorrected (upper row) and the bias-corrected (lower row) RCMs and their ensemble-mean. Compared to rainfall change distribution, the projected R1mm distributions change of RCMs generally follow the same patterns. We should note that the LS correction does not influence pretty much the R1mm change in Senegal as seen in figure 4. Similar behavior is observed in the R20mm projected change distributions, however little differences namely on the structures of the change have been noted (Figure 5). These results are not surprising as it's known that one disadvantage of the LS method is that the wet-day frequencies and intensities are not corrected (Lenderink et al. 2007).

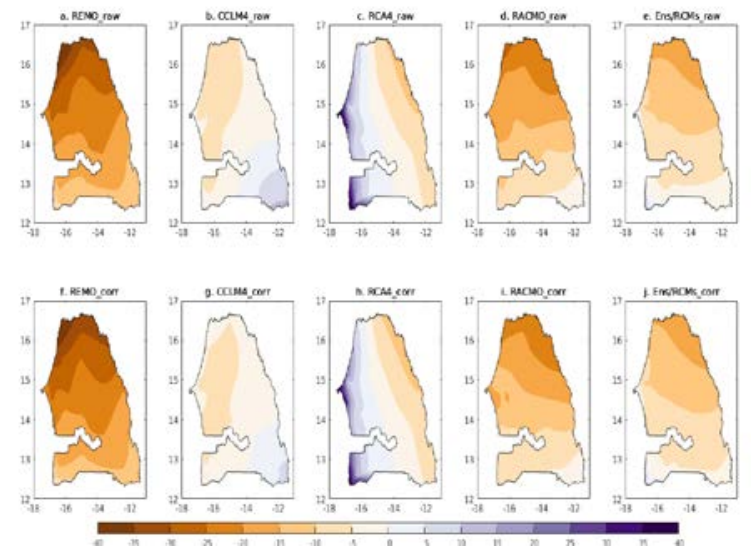

Figure 4. Same as Fig.3 but with mean summer projected number of rainy days (R1mm) 


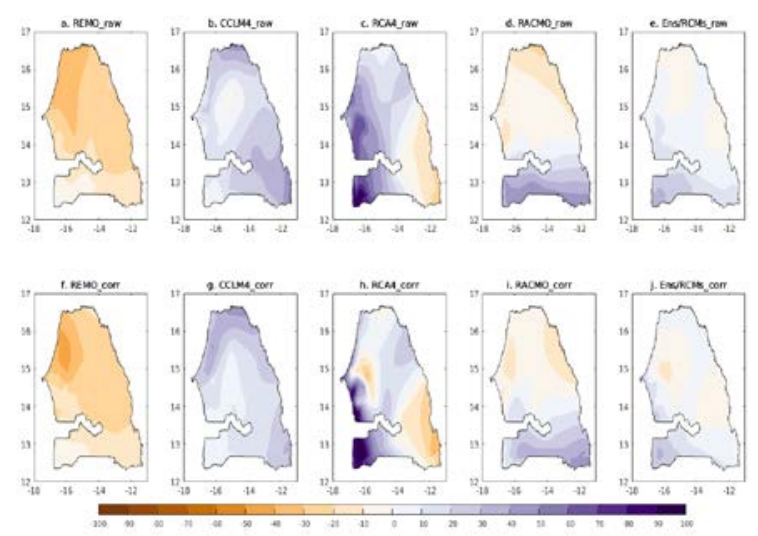

Figure 5. Same as Fig.3 but with mean summer projected frequency of heavy rainfall (R20mm)

The summer projected changes in the mean intensity of daily rainfall events (SDII) are shown in figure 6. Almost models simulate an increase of the simple daily intensity index (SDII) in the near future, except the RCA4 which shows a decrease in the eastern-south and western-north of Senegal (Fig.6.c) and the REMO which simulates also a negative change in the central northern part of Senegal (Fig.6.a). The CCLM4 seems to give the maximum percentage of change (Fig.6.b). The bias-corrected models (Figures 6.f-i) simulate similar spatial distributions change of SDII but the intensities of the signal are stronger compared to the original models namely in the south and the southern-east of Senegal.

The projected changes in the total precipitation percent due to heavy rain days (R95PTOT) are shown in figure 7. The R95PTOT corresponds to intense rainfall events. The uncorrected models REMO_raw and CCLM4_raw (Fig 7.a and Fig.7.b, respectively) generally present an increase of the R95PTOT (more than 10\%) over Senegal. Nevertheless, the CCLM4_raw shows a slight decrease over the extreme north and extreme southwest of the country. The RACMO_raw (Fig. 7.d) exhibits an increase in the western band of the country and the northern. However, the R95PTOT is decreasing in the center. Unlike other models, the RCA4_raw shows almost a decrease of R95Ptot over the whole country and a slight increase toward the north-east as shown in figure 7.c. The decreasing pattern obtained with this model could reach $30 \%$ toward the west of the country. A slight increase is also found in the uncorrected ensemble-mean (Fig. 7.e). The spatial patterns observed in the uncorrected models seem to be similar to those observed in the bias-corrected models. However, the magnitude of the changes is slightly less important in the CCLM4_corr and RCA4_corr (Fig. 7.g and Fig. 7.h, respectively) and conversely more pronounced in the REMO_corr, the RACMO_corr and the 
ensemble-mean bias-corrected (Fig. 7.f, Fig. 7.i, and Fig. 7.j, respectively) compared to their corresponding uncorrected models.

It should be noted that the large increase of change in the R95PTOT and the SDII predicted by the majority of the models (except RCA4) may be translated by a future strengthening of natural disasters such as floods. These results are also in agreement with previous findings (Giorgi et al. 2011, 2014, Sylla et al. 2016 and Diallo et al. 2016).

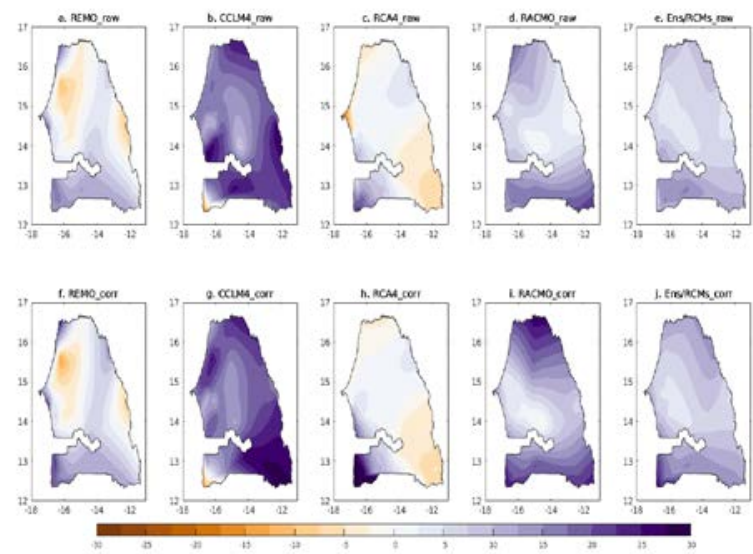

Figure 6. Same as Fig.3 but with mean summer projected simple daily intensity index (SDII)

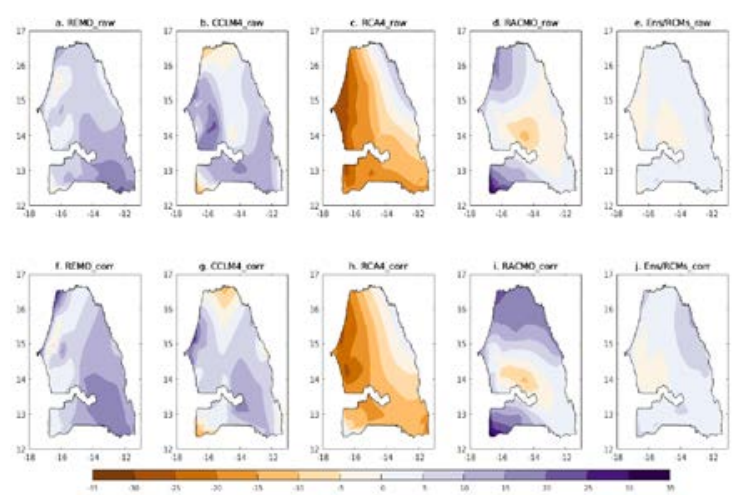

Figure 7. Same as Fig.3 but with mean summer projected very wet days (R95Ptot)

The last part of this paper is devoted to the analysis of dry spell lengths (CDD) and wet spell lengths (CWD) as illustrated in figures 8 and 9. The REMO_raw, the RACMO_raw, and the ensemble-mean show more dry spell lengths in the near future in the whole Senegal with more intensity on the north (Figs. 8.a, 8.d and 8.e). The CCLM4_raw and the RCA4_raw also project an increase of dry spell lengths from the center of the country to the north. They also project a decrease of the CDD in the eastern-south (CCLM4_raw) and in 
a localized area up to the west of Gambia as presented in figures 8.b. and 8.c. When considering the biases corrected models (figures 9.f-i), we note generally similar patterns than previously. Nevertheless, the magnitudes of the change signal are generally slightly lower and less localized in space. As a large increase in consecutive dry days (CDD) implies a large decrease in consecutive wet days (CWD), most of the models display a reduction of the CWD in the mid-twenty-first century (Figure 9). However, the CCLM4_raw model (Fig. 9.b) shows a slight increase in the south and extreme north of Senegal, whereas the RCA4_raw exhibits a positive percentage of change in the west band of the country suggesting an increase of wet spell lengths in the near future under the RCP8.5 as illustrated in figure 9.c. The remaining uncorrected models project almost a decrease of the CWD in the whole Senegal. The ensemble-mean model shows a similar pattern but with little patches where the changes are positive in the western-south and near Mbour in the south of Dakar (Fig.9.e). The spatial distribution of future changes obtained after bias correction is generally similar to the uncorrected ones. Contrary to the previous analysis (CDD), the magnitude of the negative changes is generally more pronounced. For example, the REMO_corr, the RACMO_corr and the ensemble_mean bias-corrected (Figs. 9.f, 9.h, and 9.j, respectively) show more spatial extend in the maximum of the change compared to the corresponding uncorrected models. An opposite pattern is observed with the positive change, the corrected models seem to reduce the percentage of change in the near future as projected by the CCLM4_corr and RCA4_corr and illustrated in figure 9.g et 9.h As pointed out by others authors (Lintner et al. 2012; Sylla et al. 2016), the decrease in CWD predicted by almost all models during the near future is a response to the increasing global warming. In any case, the large increase (decrease) in CDD (CWD) could affect some economic activities such as agriculture which represents an important income for Senegal.

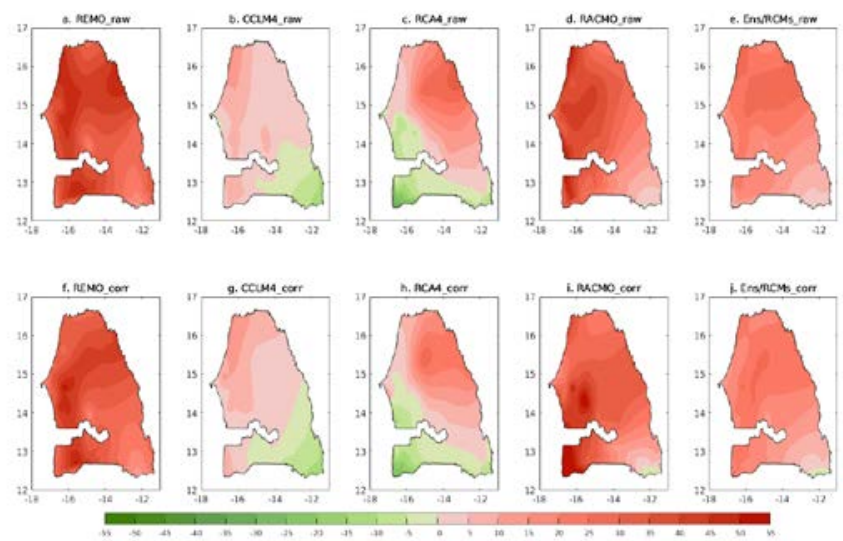

Figure 8. Same as Fig.3 but with mean summer projected maximum dry spell length (CDD) 


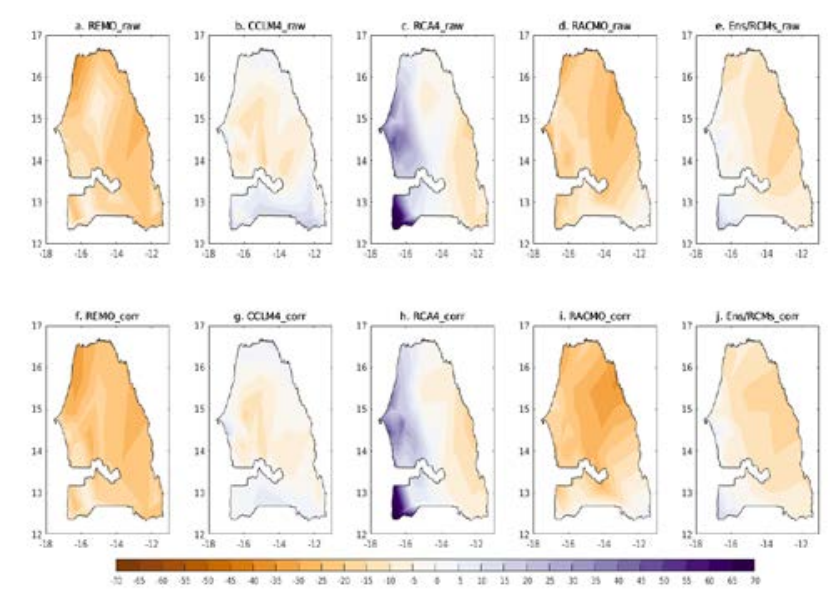

Figure 9. Same as Fig.3 but with mean summer projected maximum wet spell length (CWD)

\section{Conclusion}

The study presented here aims to evaluate the impact of bias correction on precipitation in the present (1976-2005) and the near future (2036-2065) over Senegal under the RCP8.5 scenario. The Linear scaling method has been applied on the outputs simulations of high-resolution rainfall data $\left(0.44^{\circ} \times 0.44^{\circ}\right)$ of four (4) regional climates models (CCLM4, RACMO, RCA4, and REMO) engaged in the CORDEX program. The first step was to calibrate and validate the linear scaling bias correction method during the 1976-1990 and 1991-2005 periods, respectively. The results show a good performance of the LS bias correction method during the validation period. The results obtained in the projected simulations show generally a decrease in mean precipitation in the mid-twenty-first century compared to the historical period (1976-2005). However, a slight increase is exhibited by the CCLM4 over all the country and by the RCA4 in the eastern part of the country. The applied bias correction method did not modify the spatial distribution of the precipitation changes, but the projected changes (increase or decrease) seem generally to be more intense in bias-corrected models. The analysis of the future extreme precipitation shows that the spatial pattern of the R1mm and R20mm follows the mean rainfall behavior. However, the areas where the $\mathrm{R} 20 \mathrm{~mm}(\mathrm{R} 1 \mathrm{~mm})$ is decreasing, are less (more) extended. The reverse is noted when we consider the increase patterns. The spatial distribution observed in the uncorrected models is also so much modified in the bias-corrected models, but the magnitude of the change is generally small in the bias-corrected models. A general trend of increasing precipitation intensity indices (SDII and R95Ptot) is observed over almost the whole of Senegal, except for the RCA4 that simulates a decrease of R95PTOT overall the country. The LS method 
slightly increases the magnitude of the SDII. As for the R95PTOT, the magnitude of the changes is lower in the CCLM4 and RCA4 bias-corrected and higher in the REMO, the RACMO, and the ensemble-mean model. The analysis of the mean maximum dry spell lengths (CDD) and the mean maximum wet spell lengths (CWD) shows that the RCMs generally project an increase (decrease) of the CDD (CWD). However, the RCA4 model shows a slight decrease (increase) of the CDD (CWD) over the east of the country; this situation could involve an increase of intense droughts with disastrous consequences for local economic activities. The climate change signal has slightly decreased in the bias-corrected models for the CDD index. When we consider the CWD index, the bias correction tends to slightly increase the climate change signal in the REMO and RACMO models as well in the multimodel ensemble-mean and decrease it in the CCLM4 and RCA4 models.

Finally, our results show the Linear scaling bias correction method does not affect the spatial distribution of the climate change signal but modifies it either by amplifying the magnitude or by altering the signal. Nevertheless, the bias corrections play a large role in assessing the climate change impacts on hydrology and agriculture, it is important to test several bias correction methods to better prevent climate change and apply relevant adaptation measures.

\section{Abbreviations}

CORDEX, Coordinated Regional climate Downscaling Experiment ;

RCP, Representative Concentration Pathway; UTM, Universal Transverse Mercator

\section{Acknowledgements}

The authors would like to thank the Assane Seck University of Ziguinchor for its support

\section{References:}

1. Ahmed, KF., Wang, G., Silander, J., Wilson, AM., Allen, JM., Horton, R., Anyah, R. (2012). Statistical downscaling and bias correction of climate model outputs for climate change impact assessment in the U.S. northeast. Global and Planetary Change 100 (2013) 320-332. http://dx.doi.org/10.1016/j.gloplacha.2012.11.003

2. Akinsanola, A., Ajayi, V., Adejare, A., et al. (2018). Evaluation of rainfall simulations over West Africa in dynamically downscaled CMIP5 global circulation models. Theor Appl Climatol 132, 437-450 (2018) doi:10.1007/s00704-017-2087-8.

3. Baldauf, M., Seifert, A., Förstner, J., Majewski, D., Raschendorfer, M., Reinhardt, T. (2011). Operational convective-scale numerical weather 
prediction with the COSMO model: description and sensitivies. Mon. Wea. Rev. doi:10.1175/MWR.-D-10-05013.1.

4. Camara, M., Diédhiou, A., Sow, BA., Diallo, MD., Diatta, S., Mbaye, I., Diallo, I., (2013). Analyse de la pluie simulée par les modèles climatiques régionaux de CORDEX en Afrique de l'Ouest. Sécheresse, 2013, Volume 24, $\mathrm{N}^{\circ} 1$.

5. Christensen, OB., Drews, M., Christensen, JH., Dethloff, K., Ketelsen, K., Hebestadt, I., and Rinke, A. (2008). The Hirham Regional Climate Model Version 5. Technical Report 06-17, DMI. http://www.dmi.dk/dmi/en/print/tr06-17.pdf

6. Dahm, RJ., Singh, UK., Lal, M., Marchand, M., Sperna Weiland, FC., Singh, SK., and Singh, MP (2016). Downscaling GCM data for climate change impact assessments on rainfall: a practical application for the Brahmani-Baitarani river basin, Hydrol. Earth Syst. Sci. Discuss., https://doi.org/10.5194/hess-2015-499.

7. Diatta, S.; Diedhiou, C.W.; Dione, D.M.; Sambou, S. (2020a). Spatial Variation and Trend of Extreme Precipitation in West Africa and Teleconnections with Remote Indices. Atmosphere, 11, 999.

8. Diallo, I., Giorgi, F., Deme, A., Tall, M., Mariotti, L., and Gaye, AT. (2016). Projected changes of summer monsoon extremes and hydroclimatic regimes over West Africa for the twenty-first century," Climate Dynamics, 2016.

9. Gbobaniyi, E., Sarr, A., Sylla, MB., Diallo, I., Lennard, C., Dosio, A., et al. (2014). Climatology, annual cycle and interannual variability of precipitation and temperature in CORDEX simulations over West Africa. International Journal of Climatology. 34(7):2241- 2257.

10. Giorgi, F., Jones, C., Asrar, G. (2009). Addressing climate information needs at the regional level: The CORDEX framework. WMO Bulletin. 2009;58175-183.

11. Giorgi, F., Im, ES., Coppola, E., Diffenbaugh, NS., Gao, XJ., Mariotti, L., and Shi, Y. (2011), Higher hydroclimatic intensity with global warming, J. Clim., 24, 5309- 5324.

12. Giorgi, F., Coppola, E., Raffaele, F., Diro, GT., Fuentes-Franco, R., Giuliani, G., Mamgain, A., Llopart, MP., Mariotti, L., and Torma, C. (2014b). Changes in extremes and hydroclimatic regimes in the CREMA ensemble projections. Climatic Change, 125, 39-51. doi:10.1007/ s10584-014-1117-0.

13. Hawkins, E., Ho, CK., Osborne, T., and Challinor, AJ. (2012). Calibration and bias correction of climate projections for crop modeling: an idealized case study over Europe. Ag. For. Met., in press, doi:10.1016/j.agrformet.2012.04.007. 
14. Hayhoe, K., Wake, CP., Huntington, TG., et al. (2007). Past and future changes in climate and hydrological indicators in the US Northeast. Clim Dyn 28, 381-407 (2007). https://doi.org/10.1007/s00382-0060187-8.

15. Imbery, F., Plagemann, S., Namyslo, J. (2013). Processing and Analysing an Ensemble of Climate Projections for the Joint Research Project KLIWAS. Advances in Science and Research 10:91-98. DOI: 10.5194/asr-10-91-2013

16. Jacob, D., Barring, L., Christensen, OB., Christensen, JH., Hagemann S., Hirschi, M., Kjellström, E., Lenderink, G., Rockel, B., Schar, C., Seneviratne, SI., Somot, S., van Ulden, A., and van den Hurk B (2007). An Inter-Comparison of Regional Climate Models for Europe: Design of the Experiments and Model Performance. Climate Change, 81, 3152. http://dx.doi.org/10.1007/s10584-006-9213-4.

17. Kim, J., Waliser, DE., Mattmann, CA., et al. (2014). Evaluation of the CORDEX-Africa multi-RCM hindcast: Systematic model errors. Climate Dynamics. 2014;42(5-6):1189-1202.

18. Ledoux, H., Gold C (2005). An Efficient Natural Neighbour Interpolation Algorithm for Geoscientific Modelling. In: Developments in Spatial Data Handling. Springer, Berlin, Heidelberg. https://doi.org/10.1007/3-540-26772-7_8

19. Lenderink G., Buishand A., and van Deursen, W. (2007). Estimates future discharges of the river Rhine using two scenario methodologies: direct versus delta approach, Hydrol. Earth Syst. Sci.,11, 1145-1159, doi:10.5194/hess-11-1145-2007.

20. Lintner, BR., Biasutti, M., Diffenbaugh, NS., Lee, J.E., Niznik, MJ, \& Findell, KL. (2012). Amplification of wet and dry month occurrence over tropical land regions in response to global warming. Journal of Geophysical Research, 117, D11106. doi:10.1029/2012JD017499.

21. Ly, M., Traoré, SB., Alhassane, A., Sarr, B. (2013). Evolution of Some Observed Climate Extremes in the West African Sahel. Weather and Climate Extreme, 19-25, http://dx.doi.org/10.1016/j.

22. van Meijgaard, E., van Ulft, LH., van de Berg, WJ., Bosveld, FC., van den Hurk, BJJM., Lenderink, G., Siebesma, AP. (2008). The KNMI regional atmospheric climate model, version 2.1, KNMI Tech. Rep. 302, De Bilt, Netherlands.

23. Mahmood R., Jia S. , Tripathi N. K. and Shrestha S. (2018). Precipitation Extended Linear Scaling Method for Correcting GCM Precipitation and Its Evaluation and Implication in the Transboundary Jhelum River Basin. Atmosphere 2018, 9, 160; doi:10.3390/atmos9050160 
24. Mbaye, ML., Haensler, A., Hagemann, S., Gaye, AT., Moseley, C. \& Afouda, A. (2016). Impact of statistical bias correction on the projected climate change signals of the regional climate model REMO over the Senegal River Basin. Int. J. Climatol. 36: 2035-2049.

25. Mendez M., M. Ben, Hein-Griggs D. and Alvarado-Gamboa L. (2020). Performance Evaluation of Bias Correction Methods for Climate Change Monthly Precipitation Projections over Costa Rica. Water 2020, 12, 482; doi:10.3390/w12020482

26. Moss, R., Babiker, M., Brinkman, S., Calvo, E., et al. (2010): Towards new scenarios for analysis of emissions, climate change, impacts and response strategies. IPCC expert meeting report, Noordwijkerhout, The Netherlands.

27. Nikulin, G., Jones, C., Giorgi, F., Asrar, G., Büchner, M., CerezoMota, R., et al. (2012). Precipitation climatology in an ensemble of CORDEX-Africa regional climate simulations. Journal of Climate. 2012;25:6057-78.

28. Paeth, H., Capo-Chichi, A., Endlicher, W. (2008). Climate change and food security in tropical West Africa. Erdkunde. 2008;62: 101-15. http://dx.doi.org/10.3112/erdkunde.2008.02.01.

29. Peterson, TC., Folland, C., Gruza, W., Hogg, G., Mokssit, A., \& Plummer, N. (2001). Report on the activities of the working group on climate change detection and related rapporteurs 1998-2001,” WMO Rep.WCDMP 47,WMO-TD 1071

30. Salack, S., Sultan, B., Oettli, P., Muller, B., Gaye, AT., Hourdin, F. (2012). Représentation de la pluie dans les modèles climatiques régionaux et application à l'estimation des rendements en mil. Sécheresse. 2012b;23(1).

31. Samuelsson, P., Jones, CG., Willen, U., Ullerstig, A., Gollvik, S., Hansson U, \& al. (2011): The Rossby centre regional climate model RCA3:model description and performance. Tellus A 63: 4-23.

32. Sarr, AB., Camara, M., \& Diba, I. (2015) Spatial Distribution of Cordex Regional Climate Models Biases over West Africa. International Journal of Geosciences, 6, 1018-1031. http://dx.doi.org/10.4236/ijg.2015.69081.

33. Sarr, AB., \& Camara, M. (2017). Evolution des indices pluviométriques extrêmes par l'analyse de modèles climatiques régionaux du programme CORDEX : Les projections climatiques sur le Sénégal. European Scientific Journal. Vol.13, No.17 ISSN: 18577881 (print)e-ISSN1857-7431.doi:10.19044/esg.2017.v13n17p206.

34. Shrestha, M., Acharya, SC., \& Shrestha, PK. (2017). Bias correction of climate models for hydrological modeling - are simple methods still useful? Meteorol. Appl. 24: 531-539 (2017). DOI: 10.1002/met.1655. 
35. Sillmann J, Kharin V, Zwiers F, Zhang X, Bronaugh D (2013). Climate extremes indices in the CMIP5 multimodel ensemble: Part 2. Future climate projections. J Geophy Res Atmos 118:2473-2493

36. Sylla, MB., Nikiema, PM., Gibba, P., Kebe, I., Klutse, NAB. (2016). Climate Change over West Africa: Recent Trends and Future Projections. Yaro, JA., and Hesselberg, J. (eds.), Adaptation to Climate Change and Variability in Rural West Africa, DOI10.1007/978-3-31931499-0_3.

37. Teutschbein C. and Seibert J. (2013). Is bias correction of regional climate model (RCM) simulations possible for non-stationary conditions? Hydrol. Earth Syst. Sci., 17, 5061-5077. doi:10.5194/hess-17-5061-2013

38. Van der Linden, P., \& Mitchell, JFB. (2009). ENSEMBLES: Climate Change and Its Impact: Summary of Research and the results from the ENSEMBLES Project. Met Office Hadley Centre, Exeter: Toward an understanding of meditation and consciousness. Cambridge, MA: MIT Press.

39. Willkofer F., Schmid F., Komischke H., Korck J., Braun M., Ludwig R. (2018). The impact of bias correcting regional climate model results on hydrological indicators for Bavarian catchments. J. of Hydro.:Regional Studies 19, 25-41

40. Worku, G., Teferi, E., Bantider, A. et al. Statistical bias correction of regional climate model simulations for climate change projection in the Jemma sub-basin, upper Blue Nile Basin of Ethiopia. Theor Appl Climatol 139, 1569-1588 (2020). https://doi.org/10.1007/s00704019-03053-X

41. Zhang, X.; Alexander, L.; Hegerl, G.C.; Jones, P.; Tank, A.K.; Peterson, T.C.; Trewin, B.; Zwiers, F.W. (2011). Indices for monitoring changes in extremes based on daily temperature and precipitation data. Wiley Interdiscip. Rev. Clim. Chang. 2, 851-870, doi:10.1002/wcc.147. 